\title{
The Legitimacy of Democracy and Trust in the Political Institutions in the Czech Republic*
}

\author{
KLÁRA VLACHOVÁ ${ }^{* *}$ \\ Institute of Sociology, Academy of Science of the Czech Republic, Prague
}

\begin{abstract}
This article deals with legitimacy of democracy and its relationship to trust in political institutions in the Czech Republic. The introduction includes a recapitulation of the theories concerning the legitimacy of democracy, and on the conditions necessary for this legitimacy, which is what the subject of this article is then built upon. The author distinguishes between support for democracy as a form of government, and satisfaction with the development of democracy in a (particular) country, and searches for the factors which this depends on. As explanatory factors, the author first tests trust in institutions, then political culture and personal characteristics. The analysis showed that the legitimacy of democracy and the evaluation of the development of democracy are not in the Czech Republic mutually independent, and that they depend more on political culture than on trust in the institutions being researched. For the legitimacy of democracy, a significant effect was traced only in the case of trust in NATO - an institution that also became a value in the political culture. With the evaluation of the development of democracy, trust in institutions was more strongly felt - a significant effect was revealed by an analysis of the social welfare system, the army and the media. It is clear that the evaluation of the performance of institutions is rather more reflected in the system efficacy of the democracy than in the legitimacy of democracy as a system of government.
\end{abstract}

Czech Sociological Review, 2001, Vol. 9 (No. 1: 13-33)

Once the totalitarian regimes in the countries of Central and Eastern Europe had collapsed many people at that time posed the question as to whether the democracy that had been introduced into these countries would be strong and lasting or weak and also threatened with collapse. What influences the strength of democracy? Undoubtedly an entire series of institutional and systemic conditions apply. According to Linz and Stepan [1996] no modern polis can be a democracy if it is not a state, if it lacks a free and lively civil society, if it is not an autonomous political society, if it does not guarantee and protect civil rights, if it does not possess a bureaucracy working for the government, and if it does not have an economic society.

In addition to institutional and systemic conditions, democracy requires support on the part of its citizens - their trust in its legitimacy. Many people perceive democracy in two manners: as an ideal that must be striven toward, and as an existing form of government in a specific political system [Dahl 2000]. Trust in the legitimacy of democracy has two levels: general - democracy is the best (or the 'least bad') form of government among many; and specific - democracy in a particular country is despite its failings and insufficiencies a better form of government than any others that could be set up in the given country [Diamond 1998].

*) This article was supported by grant GA ČR (No. 403/99/1129).

**) Direct all correspondence to: Klára Vlachová, Institute of Sociology, Academy of Sciences of the Czech Republic, Jilská 1, 11000 Praha 1, e-mail vlachova@soc.cas.cz 
In contemporary democracies it is common for citizens to feel dissatisfied with the way in which democracy works in their country, and at the same time to be convinced that democracy is still the best form of government [Diamond 1998]. According to how democratic a country is (and how democratic its citizens are) dissatisfaction with democracy may lead to two results: citizens may opt in favour of an undemocratic regime for their country, ${ }^{1}$ or they may give preference to introducing democratic reforms. If trust in democracy is dependent on how people evaluate the democracy in their country, then it is not in itself a value, it is rather a means for ensuring the effective functioning of democracy. It is not real legitimacy - autonomous legitimacy [Maravall 1997: 203] that consolidates democracy, but instrumental legitimacy. Only when support for democracy has become unconditional and independent of the particular functioning of the democracy is it possible to consider a democracy as being consolidated. A democracy is consolidated not only when its support is unconditional, but also when it is shared by all the main political groups and movements.

Support for democracy takes shape on three levels [Dalton 1998]:

\begin{tabular}{|l|l|l|}
\hline & Affective orientation & Evaluations \\
\hline Community & $\begin{array}{l}\text { National pride } \\
\text { Sense of national identity }\end{array}$ & Best nation to live in \\
\hline Regime: its principles & Democratic values & $\begin{array}{l}\text { Democracy best form of gov- } \\
\text { ernment }\end{array}$ \\
\hline Regime: political process & $\begin{array}{l}\text { Participatory norms } \\
\text { Political rights }\end{array}$ & $\begin{array}{l}\text { Evaluation of rights } \\
\text { Satisfaction with democratic } \\
\text { process }\end{array}$ \\
\hline Regime: political institution & $\begin{array}{l}\text { Institutional expectations } \\
\text { Support party government } \\
\text { Output expectations }\end{array}$ & $\begin{array}{l}\text { Performance judgement } \\
\text { Trust in institutions } \\
\text { Trust party system } \\
\text { Trust bureaucracy }\end{array}$ \\
\hline Authority & Identify with party & $\begin{array}{l}\text { Candidate evaluations } \\
\text { Party support }\end{array}$ \\
\hline & General support & Specific support \\
\hline
\end{tabular}

One of the levels giving rise to support for democracy is the institutional one. Institutions are legitimate as long as citizens judge them to be suitable, which means the best possible ones for their society [Lipset 1981]. In one opinion, dissatisfaction with the performance of institutions can cause a long-term weakening of the trust of some citizens in democracy. ${ }^{2}$ But, clearly, "no institution can avoid criticism from some sectors of the population. Consensus is the ridiculous claim of totalitarian regimes." [Dogan 1998: 16]. Both in old and in new democracies a weakening trust - 'confidence gap' - is referred to [Lipset and Schneider 1983]. But it is difficult to distinguish the weak popularity and legitimacy

1) The temporary restriction of democracy in Nigeria in the 1980s, in Thailand in 1991, or in Peru in 1992, accompanied by the expectation that the ensuing structural reforms would facilitate an improvement in the functioning of democracy.

2) Institutions must be capable of managing political conflict and must be democratic. Almond and Verba [1963] emphasise the degree of democracy of the structures of authority in the society. If these structures - the family, church, unions etc. - are democratic, then there is a greater likelihood that the country will also be democratic. 
of an institution and trust in it, from the weak popularity of its office-holders and trust in them. Citizens are frequently dissatisfied with those who represent an institution [Dalton 1998]. The weak popularity of the representatives of a certain institution does not necessarily mean a lack of trust in the institution itself.

Rose, Mischler and Haerpfer [1997] claim that in order for a democracy to function efficiently it is not necessary for there to also be a high degree of trust in politics or even in institutions. The research that was carried out in the post-communist countries (The New Democracies Barometer) shows that the majority of the population has no trust in any of the fifteen political and social institutions. The highest level of trust is generally directed at the president, the armed forces and the church, though the last two mentioned here do not receive the trust of even half of the population. In the Czech Republic according to this research from 1995, the most trust is placed in the media, followed by the government, the president, the armed forces, the court system, the police, political parties, the church, and parliament [Gabriel 2000]. ${ }^{3}$

If one considers what the alternative to trust in an institution is, it clearly is not distrust, but rather scepticism. Merkl [1988] believes that the ideal democratic culture is neither blindly trusting nor hostilely rejecting, but rather inquisitive and sceptical. Those who are dissatisfied may (reputedly) be good democrats who are simply interested in improving democracy. And as the manner in which people perceive the performance of a political system has changed during recent decades, the crisis in the degree of trust is primarily a sign of continuing political maturity and advancement [Dahl 2000].

Although the opinion continues to be raised claiming there is a relationship between trust in institutions and democratic legitimacy, the dominant view is that the legitimacy of democracy is to a certain degree independent of the performance of institutions. Dissatisfaction with the performance of institutions does not weaken the loyalty of citizens toward the existing regime. Responsibility for the unsatisfactory performance of institutions can in a democracy be ascribed to an entire series of sources: the economic system, the international situation, the government, employers, unions, etc. It is possible to change the government, but it is not necessary to change the regime. Dissatisfaction with institutions is entirely compatible with democracy.

When we speak of institutions whose legitimacy, or even only the affective orientations and evaluations directed toward which, are capable of having an influence on the legitimacy of democracy, we are above all referring to political institutions, in particular to the tripartite of state power: the executive - the president, the government, state administration in general, and the army and the police in particular; the legislature - parliament; and the judiciary - courts. Others generally included as being relevant in this case are the powerful and influential institutions characteristic of a civil society - the church, the media, unions, and in some cases political parties and businesses. This list goes to show that both political and economic institutions are relevant. It is not possible to discuss the legitimacy of a regime today without examining its socio-economic system [Linz 1988, Burkhart 2000]. Thus even those institutions that may be a part of both state administration and civil society - such as the education system, the social security system, and the health-care system - fall into the focus of consideration.

3) The author is presenting the average level of trust in the institutions cited also for Bulgaria, Hungary, Poland, Romania, Slovakia, Slovenia, Croatia, Belorussia, and Ukraine. 
However, the legitimacy of a democracy may even be influenced by the type of economy. Democracy is frequently perceived in association with capitalism as a single entity, and according to Schumpeter [1975] democracy is indeed the product of capitalism. But it can certainly co-exist in combination with various types of economic system, similarly to an authoritarian regime. ${ }^{4}$ Regardless of the economic system, democracy requires a certain degree of economic development, and economic development demands a certain degree of democracy. ${ }^{5}$ In connection with the collapse of the authoritarian and totalitarian regimes, Maravall [1997] reached the conclusion that changes leading in the direction of democracy come about equally owing to the economic success of a regime as owing to its economic failure. Authoritarian regimes are just as incapable of managing a long-term excellent performance in the economic sphere as they are in managing economic crisis [Dahl 2000], and democratisation is the result of both the political and economic failure of dictatorships [Maravall 1997]. Unlike undemocratic regimes, however, a legitimate democracy can survive an economic crisis.

But how well will the new democracies, born out of economic crises, actually fare? As long as new democratic governments grapple more with problems that are economic in nature they will be unable to concentrate on the political ones. If they concentrate on political problems, while economic performance remains below standard, then economic failures may lead to a weakening of the legitimacy of some institutions or even of the entire regime. While Linz and Stepan [1996] do not believe that a worsening of the economy becomes an instrument in the erosion of support for democracy, according to Diamond [1998] it is primarily economic performance that influences the level of satisfaction with how the democracy is functioning. He concedes, however, that the political performance of the regime does have an influence on the legitimacy of the democracy. ${ }^{6}$

It is therefore both the economic and the political performance of a democracy that influences its support. However, also indicated as variables mediating between the economic and political performance of a democracy and the support it receives are the beliefs, attitudes and values that are shared by the citizens of a democracy [Inkeles and Diamond 1980, Inglehart 1990, Lipset 1981]: freedom, tolerance, trust, political efficacy, participation in politics and civic life, satisfaction in life, interpersonal trust, and the rejection of revolutionary change etc. These factors go into forming a political culture. ${ }^{7}$ The legitimacy of democracy, or of others types of regime, is connected with political culture [Almond and Verba 1963], and it is political culture (i.e. the set of values, attitudes, opinions, knowledge and capabilities of citizens) that plays a significant role in the development and consolidation of democracy. It is formed in the sector located between the state and the individual, in the sector known as 'civil society'. Political parties, pressure and

\footnotetext{
4) Maravall [1997] summarises four varieties of relationships between political regimes and economic systems: the market requires a democracy, the market requires authoritarianism, the democracy requires a market, the democracy requires centrally planned and public ownership.

${ }^{5}$ ) Nothing however exists that would guarantee that the advanced country would be democratic and the poor country authoritarian or totalitarian [Maravall 1997].

${ }^{6}$ ) For example, the increase in the freedom of the individual, the way in which institutions perceive citizens and the degree of transparency of the activities of institutions can all have a positive influence. Conversely, the perception of corruption can have a negative influence.

7) In the Czech Republic, political culture is a concept thus far seriously reduced to a focus on the behaviour of politicians and political parties. 
interest groups, unions, the media, cultural foundations, professional organisations, academic societies, and commercial societies, all put forth their interests and interact with the state in this sector [Maravall 1997: 205]. It is here that democratic values are formed. However, they become anchored only over time. Democracy becomes mature at the earliest after two generations [Converse 1969, Maravall 1997]. This amount of time is necessary for the political socialisation of citizens in the new regime. ${ }^{8}$ Until that time, democracy rests on unstable foundations. ${ }^{9}$

A brief excursion into the theory of the legitimacy of democracy serves to point out that this is an extensive and multifaceted subject. For this reason the questions that will be raised in this study cover only part of the background to the setting in which the legitimacy of the democracy in the Czech Republic stands. We are interested in determining what kind of support democracy in the Czech Republic is receiving, whether support for democracy (the evaluation of the principle) depends on an evaluation of the development of democracy here (the evaluation of the political process), and conversely what kind of role is played by trust in institutions.

\section{Variables}

We are going to work with two variables which in the analyses are both the 'explained' and the 'explanatory' variables. Legitimacy of democracy (the evaluation of the form of government) is measured by means of expressing agreement or disagreement with a statement such as 'democracy is the best form of government'. In the research conducted through the European Values Study in 1999, which is also the source of our data here, the following statement was used: Democracy may have problems but it is better than any other form of government (agree strongly $=1$, disagree strongly $=4$ ). The system efficacy (the evaluation of the political process) of democracy is measured by asking whether citizens are satisfied with the way in which democracy works in their country. In the research of the European Values Study a similar question was posed: On the whole, are you very satisfied, rather satisfied, not very satisfied, or not at all satisfied with the way democracy is developing in our country? (very satisfied $=1$, not at all satisfied $=4$ )

Other explanatory variables were represented by the expression of trust in the following institutions:

1. Institutions of state power: the legislature - the Chamber of Deputies and the Senate, the executive - state administration and offices, the police, the army (trust in the government or in the president was not examined in this research), the justice system (a question on the court system was not raised in this research);

2. Some influential institutions of civil society: the press, churches, trade unions, major companies;

3. Welfare institutions: the social security system, the health-care system, the education system;

8) The process of democratisation is complicated, it brings about with it the socialisation of a new generation, but also the re-socialisation of the old generation.

9) Unanswered questions however remain as to whether the theory of political culture is capable of explaining a change in regime [Maravall 1997: 202], and whether changes in regime are preceded by changes in values and attitudes. 
4. Subregional organisation of collective defence which the Czech Republic has membership in: NATO.

The explanatory variables were also formed from the values and attitudes that go into making up political culture (political, economic and personal), and from the personal characteristics of the respondent: four various government regimes - military, authoritarian with a strong leader, limited democracy with a government of experts, and democracy - were evaluated by the respondent as being suitable or unsuitable in the case of the Czech Republic; also evaluated were the communist political regime and the current system of running the country, a scale of liberal-paternalistic economic values, interest in politics, political orientation, sense of freedom, sense of satisfaction with life, interpersonal trust, the preferred means of bringing about change in society - revolutionary, reformist, and evolutionary - and finally also the subjective categorisation of the respondent into a social class, and the respondent's age and the level of education. An outline of the explanatory variables is presented in the appendix.

\section{Legitimacy of Democracy in the Czech Republic}

In modern age history the Czech Republic has had the longest experience (1918-1938) with democracy out of all the countries of Central and Eastern Europe. This experience with democracy was rooted in the democratic institutional and systemic framework characteristic for the Western countries (sovereignty of the people, democratic institutions, limitations on state power and the division of power, constitutionalism and rule of law, a parliamentary form of government, majority decision-making and the protection of minorities, unconditional and inalienable human and civic rights, political plurality). However, this twenty-year democracy was replaced with a fifty-one year period of undemocratic forms of government: first from without, through an occupational regime (the German Nazi protectorate), then from within, with the post-war limited democracy, which was replaced at the end of the 1940s with a totalitarian, communist regime. The latter eventually, after an unsuccessful episode of democratisation in 1968, changed into a post-totalitarian regime. ${ }^{10}$ Linz and Stepan [1996: 42] refer to the regime of the second half of the 1980s, in the Czechoslovak and East German cases, as 'frozen' posttotalitarianism, in which, unlike the post-totalitarianism in Hungary or Poland, no marked political or economic reforms came about.

The legitimacy of Czechoslovak post-totalitarianism was quite low at the end of the 1980s. However, low legitimacy was definitely not in itself a cause of the collapse [Dvořáková and Kunc 1994], even though all the relevant social and professional groups in society were interested in changing the regime [Možný 1991]. But the international embeddedness of undemocratic regimes often plays a role in their long-term existence [Linz and Stepan 1996: 237-238]. In Central and Eastern Europe these illegitimate regimes were kept alive through their ties to the undemocratic hegemonic world power Russia. Only once this great power had ceased to keep them under its protective wing did the illegitimate regimes fall, as there was no one even within the regime willing to struggle for their existence.

\footnotetext{
10) In the 1980s, with the exception of Poland, according to Linz an authoritarian post-totalitarian system dominated in Central and Eastern Europe, a system that did not have complete control over the life of its citizens outside the sphere of politics. 
After the collapse of post-totalitarianism in Czechoslovakia at the end of 1989, the new political elite wasted no time in returning citizens their political rights ${ }^{\mathbf{1 1}}$ and freedoms, and carried out important political reforms (amendment of the socialist constitution), followed by economic reforms (privatisation, restitution, liberalisation of the market) and social ones. Democratisation resulted in the disintegration of the socialist federation [Pavlíček et al. 1998], the political division of the federal Czechoslovak state in 1992, and the creation of institutional and systemic foundations for the separate states - the Czech Republic and the Slovak Republic. The economic transformation initiated by the reforms brought groups of citizens collective social mobility - both upward and downward - and a sense of both social and economic gratification and deprivation. The economy went through a transformation recession, a subsequent economic boom, and after a change in monetary policy in 1996, resulting in a fiscal crisis solved by restrictive government 'packages', another economic recession. This was accelerated by the political crisis that led at the end of 1997 to the fall of the centre-right government formed by ODS, ODA and KDU-ČSL, accompanied by some unconstitutional measures taken by the president. Subsequently a government composed of non-party experts and politicians from minor parties whose ministers had left the preceding Klaus government was set up to lead the country for half a year, the premier of which was the then governor of the central bank, Tošovský.

The 1990s were rocky years in the Czech Republic. Both economically and politically, the performance of democracy and the performance of democratic institutions represented a potential risk for the legitimacy of democracy as a form of government. Nevertheless, in 1999 people in the Czech Republic still considered democracy to be the best form of regime. Almost $90 \%$ (table 1) of respondents more or less agreed with the proposition that democracy is despite its problems the best possible form of government. Unlike many consolidated democracies in Western Europe - Denmark France, Austria, Belgium, Germany, Sweden and the Netherlands, where $48-71 \%$ definitely agreed with the statement that democracy is, despite its problems, the best possible form of government - this agreement was in the case of the Czech Republic less decisive: $40 \%$ of those asked definitely agreed. People in the Czech Republic evaluate democracy similarly to people in the countries of southern Europe, in which the authoritarian regime collapsed in the middle of the 1970s (Spain and Portugal) and in Ireland, Italy and Croatia, too.

11) The right to gather in public places, to associate (both around the end of 1989) and the right to vote (in 1990). 
Table 1. Legitimacy of democracy (\%)

(Agreement with the statement 'Democracy may have problems but it's better than any other form of government')

\begin{tabular}{|c|c|c|c|c|}
\hline & $\begin{array}{c}\text { Definitely } \\
\text { agree }\end{array}$ & Agree & Disagree & $\begin{array}{c}\text { Definitely } \\
\text { disagree }\end{array}$ \\
\hline Denmark & 71.8 & 26.8 & 1.1 & 0.3 \\
\hline Greece & 65.8 & 30.9 & 2.8 & 0.5 \\
\hline France & 61.3 & 32.0 & 5.3 & 1.4 \\
\hline Austria & 59.6 & 37.2 & 2.6 & 0.5 \\
\hline Belgium & 58.4 & 33.6 & 6.2 & 1.8 \\
\hline Germany & 52.5 & 42.8 & 4.1 & 0.7 \\
\hline Sweden & 50.8 & 43.5 & 5.0 & 0.7 \\
\hline Netherlands & 48.1 & 48.2 & 3.3 & 0.3 \\
\hline Malta & 46.7 & 47.2 & 5.8 & 0.3 \\
\hline Bulgaria & 44.0 & 40.3 & 11.9 & 3.8 \\
\hline Italy & 43.7 & 50.6 & 4.8 & 0.9 \\
\hline Croatia & 43.5 & 52.1 & 4.3 & 0.1 \\
\hline Spain & 41.7 & 52.1 & 5.1 & 1.2 \\
\hline Portugal & 41.6 & 51.0 & 6.1 & 1.3 \\
\hline Ireland & 40.9 & 52.4 & 5.7 & 1.1 \\
\hline Czech Republic & 40.5 & 52.2 & 6.7 & 0.6 \\
\hline Romania & 33.9 & 44.3 & 14.9 & 6.9 \\
\hline Slovakia & 31.9 & 52.5 & 12.6 & 3.0 \\
\hline Latvia & 28.2 & 62.4 & 7.7 & 1.6 \\
\hline Slovenia & 25.4 & 64.8 & 8.7 & 1.2 \\
\hline Ukraine & 24.0 & 58.8 & 15.2 & 2.1 \\
\hline Poland & 23.6 & 65.7 & 9.3 & 1.4 \\
\hline Lithuania & 22.3 & 66.6 & 10.2 & 0.9 \\
\hline Estonia & 20.3 & 70.0 & 8.9 & 0.7 \\
\hline Russia & 11.9 & 50.5 & 31.8 & 5.8 \\
\hline Note: & ered acc & to rel & quency & he category \\
\hline Source: & & & & \\
\hline
\end{tabular}

While in the Czech Republic democracy is considered to be the best form of government by nine out of ten of those asked, only around $30 \%$ of those asked are satisfied with the development of democracy in the country (table 2). The Estonians are satisfied with the development of democracy to a degree similar to that of the Czechs, while Slovenians and Poles expressed slightly more satisfaction ( $45 \%$ and $43 \%$ of those asked). Satisfaction with the development of democracy is thus in the most successfully transforming countries of Central and Eastern Europe lower than in the consolidated democracies of Western Europe. In Western Europe, satisfaction with the development of democracy is expressed by between $50-78 \%$. Of the countries surveyed in the European Values Study, France, Belgium and Italy were located at the lower end of this interval. But who is dissatisfied? Are they the critical but 'good' democrats, or those who would elect an undemocratic regime? 
Table 2. Satisfaction with the development of democracy (\%)

(Agreement with the statement 'On the whole are you very satisfied, rather satisfied, not very satisfied or not at all satisfied with the way democracy is developing in our country?')

\begin{tabular}{|c|c|c|c|c|c|c|}
\hline \multirow[b]{2}{*}{ Portugal } & \multicolumn{2}{|c|}{ Satisfied Dissatisfied } & \multirow{2}{*}{$\begin{array}{c}\begin{array}{c}\text { Very } \\
\text { satisfied }\end{array} \\
10.0\end{array}$} & \multirow{2}{*}{$\begin{array}{c}\begin{array}{c}\text { Rather } \\
\text { satisfied }\end{array} \\
68.6\end{array}$} & \multicolumn{2}{|c|}{$\begin{array}{l}\text { Not very Not at all } \\
\text { satisfied satisfied }\end{array}$} \\
\hline & 78.6 & 21.4 & & & 18.2 & 3.2 \\
\hline Malta & 78.0 & 22.0 & 16.6 & 61.4 & 18.1 & 3.9 \\
\hline Austria & 74.8 & 25.1 & 8.2 & 66.7 & 21.8 & 3.3 \\
\hline Netherlands & 73.5 & 26.5 & 5.9 & 67.6 & 24.6 & 1.8 \\
\hline Germany & 70.8 & 29.2 & 10.0 & 60.8 & 24.4 & 4.9 \\
\hline Denmark & 67.0 & 33.0 & 12.3 & 54.7 & 30.0 & 3.0 \\
\hline Ireland & 64.4 & 35.6 & 10.2 & 54.2 & 29.3 & 6.3 \\
\hline Spain & 60.5 & 49.5 & 6.6 & 53.9 & 33.3 & 6.2 \\
\hline Sweden & 56.0 & 38.0 & 2.9 & 53.2 & 32.4 & 5.6 \\
\hline Greece & 55.3 & 44.7 & 7.5 & 47.8 & 35.8 & 9.0 \\
\hline France & 49.4 & 50.6 & 4.4 & 45.0 & 39.4 & 11.2 \\
\hline Belgium & 47.1 & 52.9 & 2.2 & 44.9 & 35.6 & 17.3 \\
\hline Slovenia & 45.0 & 55.0 & 0.9 & 44.1 & 44.4 & 10.6 \\
\hline Poland & 43.1 & 56.9 & 2.2 & 40.9 & 42.4 & 14.5 \\
\hline Czech Republic & 37.7 & 62.3 & 0.9 & 36.8 & 49.4 & 12.9 \\
\hline Estonia & 36.7 & 63.3 & 2.0 & 34.7 & 51.2 & 12.2 \\
\hline Italy & 35.9 & 64.1 & 1.6 & 34.3 & 52.7 & 11.4 \\
\hline Lithuania & 30.3 & 69.7 & 1.3 & 29.0 & 59.5 & 10.3 \\
\hline Bulgaria & 28.5 & 71.5 & 2.7 & 25.8 & 49.8 & 21.7 \\
\hline Latvia & 25.5 & 74.5 & 1.9 & 23.6 & 52.1 & 22.5 \\
\hline Slovakia & 23.4 & 76.6 & 0.8 & 22.6 & 52.8 & 23.8 \\
\hline Romania & 20.9 & 79.1 & 1.7 & 19.2 & 52.2 & 26.9 \\
\hline Croatia & 17.9 & 82.1 & 1.7 & 16.2 & 55.7 & 26.4 \\
\hline Ukraine & 15.4 & 84.6 & 1.3 & 14.1 & 48.9 & 35.7 \\
\hline Russia & 6.9 & 93.1 & 0.5 & 6.4 & 42.0 & 51.2 \\
\hline
\end{tabular}

Note: $\quad$ Countries are ordered according to relative frequency in the category

Source: 'Very satisfied' and 'Rather satisfied'. EVS 1999.

In the research conducted by the European Values Study respondents were asked how suitable they feel each of four types of regimes would be for their country: a regime run by the armed forces, by a strong leader, by experts, or a democratic regime. A military regime received support from not quite 3\% of the population, $17 \%$ supported a regime with a strong leader, 53\% agreed that a government of experts would be suitable, and $93 \%$ of respondents considered democracy to be the most suitable form (graph 1). ${ }^{12}$ Democracy is considered as a suitable regime for the Czech Republic by 3\% more respondents than those who consider democracy generally to be the best system. A similar disparity, in which more respondents consider democracy to be a suitable regime for their country than consider democracy generally as the best form of regime, was found, for example, in the case of Spain. Thus ten years after the fall of the undemocratic regime,

12) In Russia, Ukraine and Belorussia a relatively high level of support was found for restricting parliament, in favour of a strong leader, and for a return to communism [Diamond 1998]. 
democracy is, despite its vicissitudes, failings, and the political and economic crises, considered by the majority of the population to be the best form of regime in general and the most suitable regime for the Czech Republic in particular. The absolute majority of critics therefore clearly belong to the category of 'good' democrats who are interested in improving the way in which the renewed democracy and its institutions work.

Graph 1. Evaluation of political regimes as methods of running our country (\%)
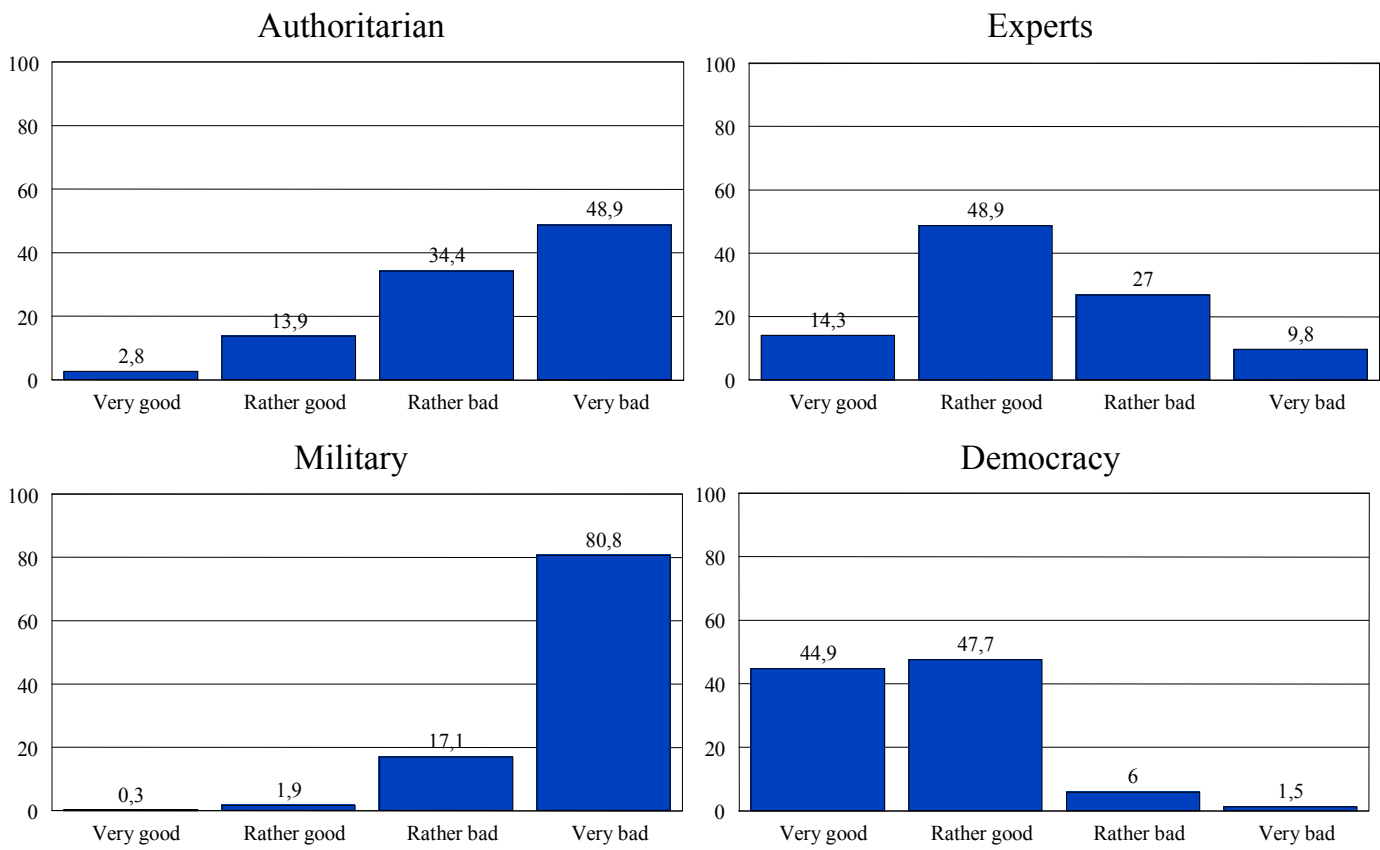

Source: $\quad$ EVS 1999.

However, in each country we come across an entire range of ideas on how to improve democracy and democratic institutions - each political party has its own idea. In the Czech Republic also satisfaction with the way in which democracy functions is a matter linked to political orientation, or to voting preferences. Crosstabs analysis shows that people who support right-wing political parties are more satisfied with the development of democracy in the Czech Republic than are the voters of left-wing parties. ${ }^{13}$ Roughly $55 \%$ of ODS and US supporters are satisfied with democracy, while conversely $72 \%$ of ČSSD supporters and $80 \%$ of Communist party supporters are dissatisfied. If Citrin's [1974] claim is true, that the dissatisfied are usually those whose parties are in the opposition, then the greater satisfaction among right-wing voters in this case may stem from the fact that the right wing and the centre have had a greater period of influence on institutional and structural conditions in the country since the collapse of post-totalitarianism than the left wing has (by the year 2000 the ratio was 6 years to 2). Moreover the most significant and also politically the most controversial reforms (privatisation of state prop-

13) Conversely, in Spain those most dissatisfied with the functioning of democracy are people with a rightwing orientation [Diamond 1998]. 
erty, construction of the social security system, and some modifications to the health-care and other systems) occurred under the direction of the right and centre.

The fact that voters of different political parties differ in their degree of satisfaction with how democracy functions is nothing strange. Dissatisfaction and varying ideas on how democracy should work are reflected in various political programmes, and do not represent a risk to democracy. There is no risk as long as a large number of voters refrain from adopting the opinion that democracy is not the best regime for the Czech Republic. A risk could emerge if the political contest ceased to be one in which only various options for improving the functioning of the institutions and structural conditions of democracy compete, and instead became one in which the very existence of democracy itself entered into the competition. In the political 'market', it is the so-called anti-system parties, usually communist and fascist ones, that cast doubts on the existence of democracy. In the Czech Republic, this kind of anti-system party in parliamentary politics is typified in the Communist party (KSČM), and even though democratic rules of the game have been in practice for over ten years now, the communists still represent a group with a specific political culture. Around $26 \%$ of communist voters do not consider democracy as a legitimate regime, while there are significantly fewer voters of pro-system parties who share this attitude: ČSSD 6.5\%, KDU-ČSL 4\%, ODS $2 \%$, and US $1.5 \%$.

Graph 2. Trust in institutions (\%)

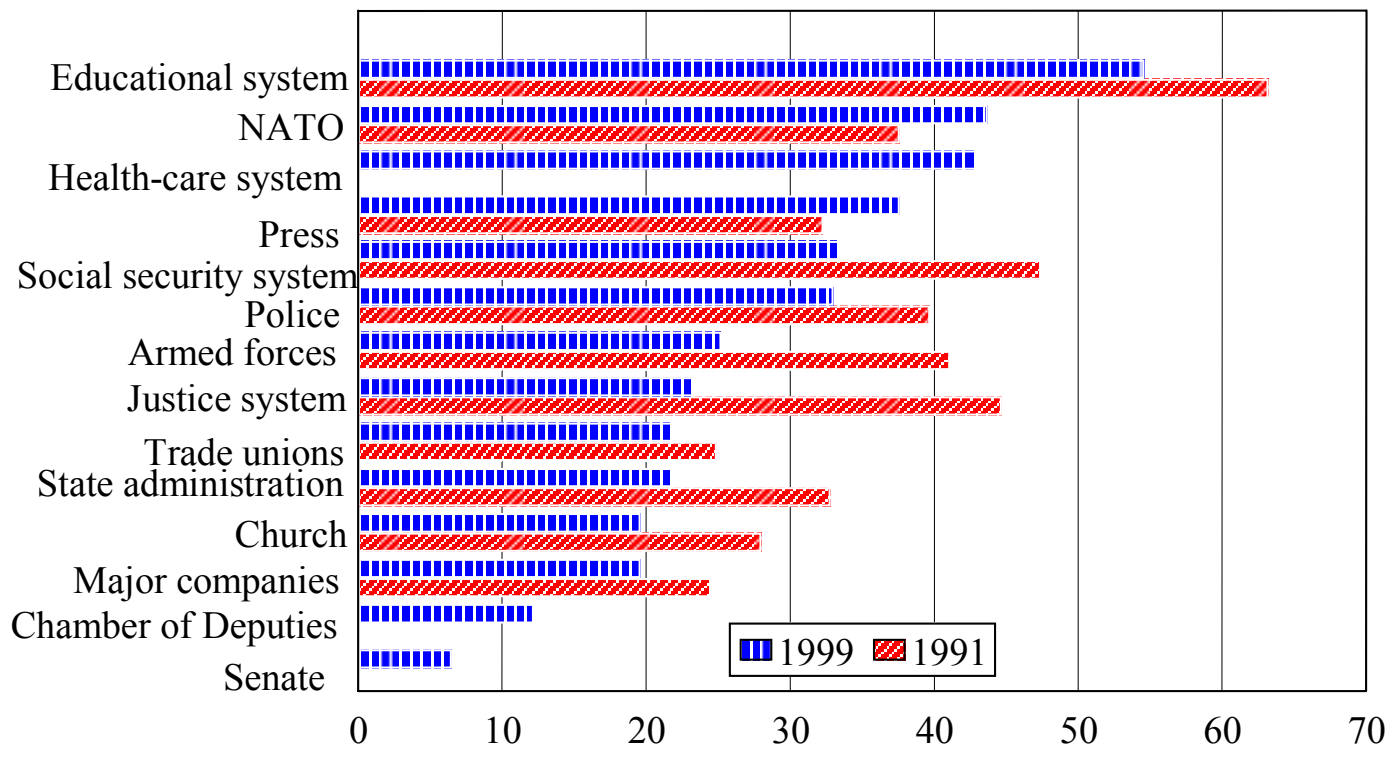

Note: $\quad$ The sum of responses 'A great deal' and 'Quite a lot' of trust. The points 'Healthcare system', 'Chamber of Deputies' and 'Senate' were present only in the questionnaire from the year 1999.

Source: $\quad$ EVS 1991, 1999.

As we mentioned in the introduction, dissatisfaction with the way democracy works (system inefficacy) is considered by some to be the result of the poor functioning of institutions, or of dissatisfaction with the functioning of institutions and a lack of trust in them. Graph 2 shows the level of trust in various institutions in 1999, and for a comparison in 1991, too. On the whole it is clear that trust in institutions since 1991 has primarily fallen, 
and has grown only in the case of NATO and the press. Only one of the institutions here examined - the education system - has, despite the decline in the level of trust in it, managed to maintain the trust of more than half the population. In 1999 people showed the least trust in Parliament. The Chamber of Deputies maintained the trust of roughly $12 \%$ and the Senate of about $7 \%$ of respondents. We will not speculate as to the source behind the low level of trust in the individual institutions because there is not enough space here to take up this matter. But in the case of the Senate, we might point out that from its very foundation it was an institution with a very low level of legitimacy, and the majority of citizens had doubts about the purpose of its existence [Vlachová 2000]. ${ }^{14}$

Table 3. Correlations

Legitimacy of democracy Satisfaction with democracy

\begin{tabular}{|c|c|c|}
\hline Education system & -0.005 & $0.070^{\text {** }}$ \\
\hline NATO & $0.409^{\star \star \star}$ & $0.332^{\star \star \star}$ \\
\hline Health-care system & $0.053^{*}$ & $0.127^{\star \star \star}$ \\
\hline Press & $0.060^{\star *}$ & $0.139^{\star \star \star}$ \\
\hline Social security system & $0.137^{\star \star \star}$ & $0.221^{\star \star \star}$ \\
\hline Police & $0.077^{\star *}$ & $0.186^{\star \star \star}$ \\
\hline Armed forces & $0.054^{* *}$ & $0.144^{\star \star *}$ \\
\hline Justice system & $0.064^{* *}$ & $0.194^{\star \star *}$ \\
\hline Trade unions & $-0.068^{* *}$ & 0.026 \\
\hline State administration & $0.080^{\star \star}$ & $0.203^{\star \star \star}$ \\
\hline Church & $0.095^{\star * \star}$ & $0.081^{\star \star}$ \\
\hline Major companies & 0.035 & $0.167^{\star \star \star}$ \\
\hline Chamber of Deputies & $0.131^{\star \star *}$ & $0.201^{\star \star \star}$ \\
\hline Senate & $0.090^{\star \star \star}$ & $0.189^{\star \star \star}$ \\
\hline $\begin{array}{l}* * * \\
0.01 \\
0.0\end{array}$ & $\begin{array}{l}t \text { at } 0.001 \\
\text { icant at } 0\end{array}$ & gnificant \\
\hline Source: & & \\
\hline
\end{tabular}

Diamond [1998] has found evidence to show that there exists a direct relationship between trust in institutions and the legitimacy of democracy, or, as the case may be, the preference for undemocratic alternatives of government. Those who place trust in institutions more often support the existing regime than do the sceptics. Table 3 shows the results of the correlation analysis for the Czech Republic. The legitimacy of democracy (the evaluation of the form of government) is significantly correlated to trust in the majority of the institutions included in the survey, with the exception of the education system and major companies. The five institutions with the greatest correlation (the correlation coefficient is statistically significant at the level of 0.001) between trust and the legitimacy of democracy are NATO, the social security system, the Chamber of Deputies, the church and the Senate. Satisfaction with the development of democracy in the Czech Republic (system efficacy) is quite significantly correlated to trust in the majority of the institutions (included in the research). A statistically significant relationship was not traced only in the case of trust in trade unions. Among the five institutions which show a strong correla-

14) Moreover, even from the viewpoint of political science, the second (upper/lower) chamber of Parliament, in which representatives of the states of the federation and representatives of the regions do not sit, is unique, and its significance is a source of contention. 
tion between trust and satisfaction with the development of democracy in the Czech Republic are NATO, the social security system, state administration, the Chamber of Deputies, and the justice system, although a very significant correlation (significant at the level 0.001 ) was found in the case of other institutions also. Therefore it is true that satisfaction with the development of democracy is very significantly correlated with trust in institutions, and that people who have trust in institutions are more likely to consider democracy as being legitimate. However, it is necessary to take into consideration that although the above-mentioned correlation coefficients are statistically significant they are somewhat low.

The question as to whether trust or distrust in institutions has an influence on the level of satisfaction with the development of democracy in the Czech Republic, and the legitimacy of democracy in general, may be answered with the help of a regression analysis. The regression analysis may also help to answer the question as to whether the legitimacy of democracy in the Czech Republic is autonomous (independent of the evaluation of the development of democracy in the country) or instrumental (dependent on the analysis of the development of democracy in the country). Two models, containing explained and mutually explanatory variables, were tested by using the method of linear regression: satisfaction with the development of democracy (the evaluation of the political process) and support for democracy as the best form of regime (the evaluation of the principle). Other explanatory variables in this analysis include trust in individual institutions, and a set of political attitudes (political culture): the evaluation of the suitability of four types of regimes in the case of the Czech Republic, the evaluation of the current system of running the country, an evaluation of the communist political system, liberalpaternalistic economic values, interest in politics, political orientation, sense of freedom, satisfaction with life, interpersonal trust, the preferred way of bringing about change in the country, and finally the characteristics of the respondent: subjective social class, age, education.

The results of the regression analysis, in which satisfaction with the development of democracy in the Czech Republic figured as a dependent variable, can be seen in table 4. Satisfaction with the development of democracy in the Czech Republic increases primarily with the rise in satisfaction with the current system of running the country, with the feeling of greater life satisfaction, with the greater inclination toward economic liberalism, with the legitimacy of democracy, with dissatisfaction with the communist political system, with the rejection of revolutionary political change, and with rise in interest in politics. With respect to trust in institutions, a statistically significant effect was traced in the case of the armed forces, the press, and the social security system. In relation to these institutions, increasing trust had an influence on the degree of satisfaction with the democracy in the Czech Republic. Trust in other institutions did not have a statistically significant influence on the degree of satisfaction here. The analysis left trust in NATO within the regression equation, but the regression coefficient is insignificant. Among personal characteristics, a statistically significant effect was found with the variables of subjective social class and age. While with the rise in social class satisfaction with the development of democracy also increased, with the increase in age it fell.

The second regression analysis used legitimacy of democracy as the dependent variable. The analysis shows (table 4) that legitimacy of democracy is above all dependent on support for democracy as the suitable means of running the country in the Czech Republic, and on satisfaction with the way in which democracy functions here and the 
rejection of the communist political regime. To a weaker degree it also depends on the rejection of a military regime. As the degree of economic liberalism and the interest in politics rise, so too does the legitimacy of democracy. With reference to trust in institutions, a statistically significant effect was traced in the case of NATO, and large businesses and companies. While the rise in the degree of trust in NATO is accompanied by a rise also in the legitimacy of democracy, in the case of major companies a negative re-

Table 4. Linear regression analysis, STEPWISE method

\begin{tabular}{|c|c|c|}
\hline & $\begin{array}{c}\text { Legitimacy of democracy } \\
\beta\end{array}$ & $\begin{array}{c}\text { Satisfaction with democracy } \\
\beta\end{array}$ \\
\hline Legitimacy of democracy & & $0.105^{\star \star \star}$ \\
\hline Satisfaction with democracy & $0.107^{\star \star \star}$ & \\
\hline \multicolumn{3}{|l|}{ Regime: leaders } \\
\hline Regime: experts & $0.052^{*}$ & \\
\hline Regime: military & $-0.052^{*}$ & \\
\hline Regime: democracy & $0.300^{* \star *}$ & \\
\hline \multicolumn{3}{|l|}{ Education system } \\
\hline \multicolumn{3}{|l|}{ Health-care system } \\
\hline Social security system & & $0.068^{* *}$ \\
\hline Armed forces & & $0.061^{*}$ \\
\hline \multicolumn{3}{|l|}{ Police } \\
\hline \multicolumn{3}{|l|}{ Justice system } \\
\hline \multicolumn{3}{|l|}{ State administration } \\
\hline \multicolumn{3}{|l|}{ Chamber of Deputies } \\
\hline \multicolumn{3}{|l|}{ Senate } \\
\hline \multicolumn{3}{|l|}{ Church } \\
\hline \multicolumn{3}{|l|}{ Trade Unions } \\
\hline Major companies & $0.054^{*}$ & \\
\hline Press & & $0.056^{*}$ \\
\hline NATO & $0.161^{\star \star *}$ & 0.052 \\
\hline Liberalism-paternalism & $0.120^{\star * *}$ & $0.114^{\star \star \star}$ \\
\hline Today's political system & & $-0.282^{* * *}$ \\
\hline Communist political system & $0.139^{\star * *}$ & $0.083^{\star *}$ \\
\hline Interest in politics & $0.065^{\star \star}$ & $-0.058^{*}$ \\
\hline \multicolumn{3}{|l|}{ Left-Right } \\
\hline \multicolumn{3}{|l|}{ Freedom } \\
\hline Satisfaction & & $-0.143^{* * *}$ \\
\hline \multicolumn{3}{|l|}{ Trust } \\
\hline Revolution & & $0.092^{\star \star \star}$ \\
\hline \multicolumn{3}{|l|}{ Reform } \\
\hline \multicolumn{3}{|l|}{ Evolution } \\
\hline Class & $-0.072^{* *}$ & $-0.052^{*}$ \\
\hline Age & $-0.048^{*}$ & $0.089^{* * *}$ \\
\hline \multicolumn{3}{|l|}{ Education } \\
\hline $\mathrm{R}^{2}$ & 0.388 & 0.338 \\
\hline Adjusted $\mathrm{R}^{2}$ & 0.383 & 0.332 \\
\hline $\begin{array}{l}{ }^{* \star *}-\text { stat } \\
0.01,{ }^{*}\end{array}$ & $\begin{array}{l}\text { y significant at } 0.001,{ }^{* *}-\mathrm{s} \\
\text { cally significant at } 0.05 \text {. }\end{array}$ & tatistically significant at \\
\hline EVS 1999. & & \\
\hline
\end{tabular}


gression coefficient shows the reverse relationship. The correlation between trust in businesses and the legitimacy of democracy is, however, positive and (at the same time) statistically insignificant, thus given this conflict it would be better to move on from the matter of the effect of trust in large businesses and companies, and leave it to future research. Among the characteristics of the respondents, similarly as in the case of satisfaction with democracy in the country, a statistically significant influence was found with respect to social class and age: both the higher the social class, and the higher the age, the greater the legitimacy of democracy.

The analyses demonstrate that legitimacy of democracy is not entirely autonomous, i.e. is not altogether independent of the evaluation of democracy in the Czech Republic, while conversely, the evaluation of the development of democracy is not independent of whether people consider democracy to be legitimate. The correlation between the legitimacy of democracy and the evaluation of its development reached 0.32 , which is somewhat more than in the countries of southern Europe, where the legitimacy of democracy had only a very weak relationship to the evaluation of the development of democracy and did not exceed 0.30 [Diamond 1998]. However, it should be noted that the evaluation of the development of democracy is not the variable with the strongest effect on the legitimacy of democracy. Higher regression coefficients were found in the case of preference in favour of democracy as a suitable system for the Czech Republic, liberal-paternalistic values, the evaluation of the communist political system (table 4) and trust in NATO. The evaluation of the development of democracy in the country is thus only one of a number of evaluative attitudes upon which the legitimacy of democracy is dependent.

If we look at the regression coefficients it is clear that the legitimacy of democracy is more dependent on the political culture than on trust in institutions. With the exception of trust in NATO (the regression coefficient is significant at the 0.001 level), the legitimacy of democracy is not dependent on trust in any of the other institutions. Similarly, the evaluation of the development of democracy in the Czech Republic depends more on political culture than on trust in institutions. Trust was found to have a significant effect only in the case of three institutions (the social security system, the armed forces, and the press, though the regression coefficients were relatively weak (they were all significant at the level 0.05).

With reference to the influence of the personal characteristics of the respondents we found that the legitimacy was dependent on, and the development of democracy was connected with the factors of subjective social class and age, though not education. ${ }^{15}$ The effect of subjective social class was the same in both cases - the higher the class that the respondent felt he belonged to, the more he considered democracy to be legitimate, and the more satisfied also he was with development in this country. The information on how the individual social classes support democracy varies. The middle class is traditionally considered to be the class that stabilises democracy, while the lower and upper classes are not quite so unambiguous. ${ }^{16}$ Democratisation literature [e.g. Linz and Stepan 1996] however presents the theory that in order for democracy to exist it also requires democratic elites - especially political ones - and not only at the outset of its existence. It is obvi-

15) Rose, Mischler and Haerpfer [1997] found a relationship in the post-communist countries between age and support for democracy. But for example in Spain this effect exists also.

${ }^{16}$ ) In Politics Aristotle already makes reference to the middle class in this way. 
ously favourable for democracy when it is supported by the middle and the upper classes, but also when it is supported by the lower class. A democratic political culture shared by all social classes is simply the most ideal situation for the existence of a legitimate democracy.

The effects of the factor of age on the legitimacy of democracy and on being satisfied with it were mutually conflicting. The older the individual the more he considered democracy to be legitimate and accepted it as the best form of government, while the younger the individual the more satisfied he was with the development of democracy in this country. The effect of education did not confirm itself. It is mentioned in some literature that support for democracy increases as the level of achieved education rises. Lipset [1981] discovered that education has a positive correlation with the kind of tolerance essential in a democracy, although a high level of education is alone not enough to stabilise democracy. Thus education is an essential condition in support for democracy, but it is by no means sufficient, and the insignificant effect of education in our analysis confirms this.

\section{Conclusion}

The evaluation of the performance of democracy, just like support for democracy in the Czech Republic, depends most on values and attitudes - on political culture - and less on trust in the examined institutions. However, exactly when the political culture that influences our support for democracy emerged, and how solid it is, are both questions. Diamond [1998] believes that it had already taken shape prior to the change from the undemocratic to the present democratic regime, through a transfer from generation to generation out of the democratic past, through social change and the process of learning and collective reflection in social groups. His assumption is that in the case of a formal transformation, a democratic political culture will lead a country to a certain degree of democracy. Political culture alone, however, is not sufficient to transform an undemocratic regime into a democratic one.

In the period between the two world wars the Czech Republic did indeed experience a democracy (unlike Hungary and Poland), but political development after 1945, and particularly after the introduction of the totalitarian system in 1948, was not exactly a consequence of democratic political culture. It is obvious that it is not possible to rely too much on a democratic past and the transfer of political culture. ${ }^{17}$ Undemocratic regimes are capable of forcing people to change in their behaviour and in the expression of their attitudes. However, they may not have such a strong impact on political values, which together with a democratic political tradition, a positive social structure, and bad experience with an undemocratic regime influence the political culture which can be positive for democracy.

All this represents a 'legitimisation bonus' for the acceptance of the new regime. Democratic consolidation is not historically determined, but certain factors can help give it an advantage. The collapse of an undemocratic regime and the ensuing openness to democratic values provides these values with the chance to again take root. The initial legitimacy of democracy is usually influenced by how it has been formed by intellectuals, political elites and the mass media. The resulting support for democracy is then stabilised

17) On the attitudes of Czechoslovak citizens toward democracy in 1968, Brokl et al. [1999]. 
along with the stabilisation of politics, and along with the way in which the elites continue to accept the democratic rules of the game. Many countries have been helped along in this respect by the experience of alternating government, changing the political parties in power, and gaining the awareness that governments change but democracy remains. Linz and Stepan [1996] deduce that in the case of the Czech Republic the previous experience with a liberal government was a help to the legitimacy of democracy. It must be added that of doubtless significance also was the alternation of parties in power after the 1998 elections into the Chamber of Deputies, and even the fact that in the 1990s only rarely did the political elites display any kind of authoritarian behaviour. ${ }^{18}$ Institutions were the sites of visible conflict (particularly parliament), but they did not undermine or subvert the existing form of government. Perhaps for this reason democracy remained legitimate, but dissatisfaction with institutions and with the development of democracy in this country emerged.

The analyses also examined that the legitimacy of democracy is not dependent on trust in the majority of researched institutions. But of real significance here is the matter of trust in NATO only. The interpretation of this relationship is not easy. The Czech Republic became a NATO member in 1999, so experience with the performance of this institution has not been long. Moreover, the question arises as to what extent NATO is perceived in this country as a democratic institution, and to what extent it is viewed rather as a value of democratic political culture. NATO is here considered to be a symbol of democracy, and NATO membership is fused with the idea of democracy as the system of government of the member countries. NATO was presented to the public in this way by the political parties that had included entry of the Czech Republic into this organisation of regional defence as one of the points in their party programmes. It was turned into even more of a value when the issue of the Czech Republic's membership became a subject of conflict between the pro-system political parties (ODA, ODS, KDU-ČSL and ČSSD), and the anti-system political parties (KSČM and SPR-RSČ). Furthermore, among those who share democratic political culture, NATO is also considered to be a symbol of having broken free from the influence of Russia and the end of the internationally anchored totalitarian system on the territory of the Czech Republic, and finally, it even represents a successful political performance by one of the democratic institutions - the government.

Linz and Stepan [1996] conclude that citizens of new democracies are capable of distinguishing between the economic and political dimensions of democracy and are able to appraise democracy according to political performance even when the economic performance is not at its best. ${ }^{19}$ Although Linz and Stepan have found a relationship between

18) President Havel received the most reproaches (for example, the fact that he announced the
senate elections 1996 in the autumn instead of the spring, when they would coincide with the elec-
tions into the house of parliament, against the will of the prime minister who must countersign this
decision and thus take responsibility for it; his acceptance of the resignation of the group of minis-
ters from the Klaus government in 1997, not from the hand of the prime minister himself, but from
the resigning ministers; his appointment of J. Tošovský as prime minister at a time when V. Klaus
was prime minister of the government in demission, etc.).
19) In some post-communist countries they proved themselves to be more perceptive and realistic
toward the economy than observers had assumed they would be [Diamond 1998]. They did not
condemn democracy for the poor performance of the economy, but rather praised the freedom
afforded by democracy, the possibility to meet freely, the freedom to think, travel, dwell and live 
economic development, or economic growth, and support for democracy, they consider the political dimension to be much more important. Our data enabled us to examine the attitudes of the population and their relationship to the legitimacy of democracy primarily in terms of the political dimension of democracy.

From the economic dimension the only aspect included in the research was trust in major companies. However, the significant association - by no means a dependency that was determined between trust in major companies and other, in particular welfare, institutions on the one hand, and satisfaction with the development of democracy on the other indicated that in the formation of satisfaction with the development of democracy and support for democracy a slight role is played by how people perceive the performance of institutions in the economic, political and social spheres. Support for democracy is not however based on trust in institutions. It is necessary to bear in mind that trust in the institutions within societies is to some degree structured by the cultural traits of that society. In the post-communist countries, the low level of trust in institutions could be a result of atomised structures and alienating experiences gained in the period of communism. This feeling may be deeply rooted, but there is nothing to rule out the possibility that political and economic development can bring about an increase in trust in institutions. The low level of trust does not have an influence on the transformation toward democracy nor on the ability of democracy to last, just as a high level of trust does not contribute to democratisation [Diamond 1998]. However, the presence of distrust in institutions within consolidated democracies supports the opinion that this is perhaps more a common trait among contemporary democracies.

Translated by Robin Cassling

KLÁRA VLACHOVÁ is senior researcher in the Institute of Sociology, Academy of Sciences of the Czech Republic. Her field of interest is the sociology of politics with a focus on voting behaviour and the development of politically relevant values and attitudes. She is co-editor (with P. Matéjü) of the book Nerovnost, spravedlnost, politika [Inequality, Justice, Politics] synthesising the renewal of consistency of objective and subjective realms of social status, changes in the perception of inequality in conception concerning social justice and transformation of political attitudes and voting behaviour in the Czech Republic between 1991-1998.

\section{References}

Almond, G. A., S. Verba 1963. The Civic Culture: Political Attitudes and Democracy in Five Nations. Princeton, NJ: Princeton University Press.

Brokl, L., A. Seidlová, J. Bečvár, P. Rakušanová 1999. "Postoje československých občanů k demokracii v roce 1968 [The Czechoslovak Citizens' Attitudes towards Democracy in 1968]." Pracovni texty 99:8. Praha: Sociologický ústav AV ČR.

Burkhart, R. E. 2000. "Economic Freedom and Democracy: Post-Cold War Tests." European Journal of Political Research 37: 237-253.

Citrin, J. 1974. "Comment: The Political Relevance of Trust in Government." American Political Science Review 68: 973-988.

Converse, P. 1969. "Of Time and Partisan Stability.” Comparative Political Studies 2: 139-171.

Dahl, R. A. 2000. “A Democratic Paradox?” Political Science Quarterly 115(1): 35-40.

without fear of unlawful imprisonment, the freedom to decide whether to participate in politics, the freedom of religion. This led to the conclusion that ideas on the legitimacy of democracy are formed more by the political than the economic functioning of the regime. 
Dalton, R. 1998. "Political Support in Advanced Industrial democracies." Irvine, CA: Center for the Study of Democracy, UC Irvine Research Papers. (www.democ.uci.edu/democ/papers/ dalton2.htm)

Diamond, L. 1998. "Political Culture and Democratic Consolidation.” (www.sscnet.ucla.edu/soc/ groups/ccsa/diamond.htm).

Dogan, M. 1998. "Legitimita režimů a důvěra v instituce: od klasické typologie k novým skutečnostem [Legitimacy of Regimes and Trust in Institutions: From a Classic Typology to New Reality]." Politologická revue 2: 111-127.

Dvořáková, V., J. Kunc 1994. O prechodech k demokracii [On Transitions to Democracy]. Praha: SLON.

Gabriel, R., 2000. “Komparace postkomunistických států z hlediska důvěry v mocenské instituce [A Comparison of Post-Communist States from the Viewpoint of Trust in Power Institutions]." SDA Info $1 / 2000$.

Inglehart, R. 1990. Culture Shift in Advanced Industrial Countries. Princeton: Princeton University Press.

Inkeles, A., L. Diamond 1980. "Personal Qualities as a reflections of Level of Natioonal Development." Pp. 73-109 in Comparative Studies in the Quality of Life, ed. by F. Andrews and A. Szalai. London: SAGE.

Linz, J. J. 1988. "Legitimacy of Democracy and the Socioeconomic System.” Pp. 65-113 in Comparing Pluralist Democracies, ed. by M. Dogan. Boulder, CO: Westview Press.

Linz, J. J., A. Stepan 1996. Problems of Democratic Transition and Consolidation. Baltimore: The Johns Hopkins University Press.

Lipset, M. S. 1981. Political Man. Baltimore: Johns Hopkins University Press.

Lipset, M. S., W. Schneider 1983. The Confidence Gap. New York: Free Press.

Maravall, J. M. 1997. Regimes, Politics and Markets. Oxford: Oxford University Press.

Merkl, P. H. 1988. "Comparing Legitimacy and Values Among Advanced Countries.” Pp. 19-64 in Comparing Pluralist Democracies: Strains on Legitimacy, ed. by M. Dogan. Boulder, CO: Westview.

Možný, I. 1991. Proč tak snadno [Why So Easy?]. Praha: SLON.

Pavlíček, V. et al. 1998. Ústavní právo a státověda [Constitutional Law and State-Science]. Praha: Linde.

Rose, R., W. Mischler, Ch. Haerpfer 1997. "Testing the Churchill Hypothesis.” Manuscript.

Schumpeter, J. A. 1975. Capitalism, Socialism and Democracy. New York: Harper and Row.

Vlachová, K. 2000. "Proměny české politické scény - strany a voliči [Changes of the Czech Political Scene: Parties and Voters].” Pp. 227-252 in Nerovnost, spravedlnost, politika, ed. by P. Matějů and K. Vlachová. Praha: SLON.

\section{Appendix}

\section{Explanatory Variables}

Regime: leader - 'Having a strong leader who does not have to bother with parliament and elections' Very good $=1$, Very bad $=4$.

Regime: experts - 'Having experts, not government, make decisions according to what they think is best for the country' Very good $=1$, Very bad $=4$.

Regime: military - 'Having the army rule the country' Very good $=1$, Very bad $=4$.

Regime: democracy - 'Having a democratic political system' Very good $=1$, Very bad $=$ 4. 
Trust in the education system, the health-care system, the social security system, the armed forces, the police, the justice system, state administration, the Chamber of Deputies, the Senate, the church, trade unions, major companies, the press, NATO - A great deal $=1$, None at all $=4$.

Liberalism-paternalism - a scale constructed from a set of eight variables. Very liberal $=$ 1 to Very paternalistic $=10$.

Today's political system - 'People have different views about the system for governing this country. Here is a scale for rating how well things are going' Very bad =1, Very $\operatorname{good}=10$.

Communist political system - 'Where on the scale would you put the communist political system?' Very bad $=1$, Very good $=10$.

Interest in politics - 'How interested would you say you are in politics?'. Very interested $=1$, Not interested at all $=4$.

Left-right - 'In politics references are made to the left wing and the right wing. Where on this scale would you rank your opinions?' Left $=1$, Right $=10$.

Freedom - 'Some people feel they have completely free choice and control over their lives, and other people feel that what they do has no real effect on what happens to them. Please use the scale to indicate how much freedom of choice and control you feel you have over the way your life turns out.' None at all $=1$, A great deal $=10$.

Satisfaction - 'All things considered, how satisfied are you with your life as a whole these days?' Dissatisfied $=1$, Satisfied $=10$.

Trust - 'Generally speaking, would you say that most people can be trusted or that you can't be too careful in dealing with people?' Most people can be trusted =1, Can't be too careful $=2$.

Revolution - 'The organisation of our society needs to be radically changed through revolutionary action' Yes $=1, \mathrm{No}=0$.

Reform - 'Our society must be gradually perfected by means of reforms'. Yes $=1$, No $=$ 0 .

Evolution - 'Let us leave society to develop peacefully on its own'. Yes $=1$, No $=0$.

Class - 'In which of the following social groups or classes would you say that you belong?' Lower class $=1$, Upper class $=6$.

Age - measured by date of birth and subsequently calculated.

Education - Uncompleted elementary education $=1$, Higher education - upper-level tertiary certificate $=8$.

Variables 'Liberalism-paternalism', 'Revolution', 'Reform' and 'Evolution' were constructed and all the variables with the exception of 'Age' were transferred into additive scales in order to make the scales comparable:

* democracy and other regimes

recode q59 q63_1 q62_1 q62_2 q62_3 q62_4 (1=0) $(2=33)(3=66)(4=99)$

into Satdem Legdem Rleader Rexpert Rmilit Rdemoc

recode $\mathrm{q} 60 \mathrm{q} 61(1=0)(2=11)(3=22)(4=33)(5=44)(6=55)(7=66)(8=77)(9=88)(10=99)$

into Dsystem Ksystem.

* liberalism-paternalism 
recode q54a q54b q54c q54d q54e2 q54f q54g q54h $(1=0)(2=11)(3=22)(4=33)(5=44)$ $(6=55)(7=66)(8=77)(9=88)(10=99)$

into individual unemploy competit freedom income private retire housing

compute libepate $=($ individual + unemploy + competit + freedom + income + private + retire + housing) $/ 8$.

* institutions

recode q58_1 q58_2 q58_3 q58_4 q58_5 q58_6 q58_7 q58_8

q58_9 q58_11 q58_13 q58_14 q58_15 q58_16 $(1=0)(2=33)(3=66)(4=99)$

into church army schools press unions police PS admin securit NATO health legal business senat.

*interest in politics

recode q51a $(1=0)(2=33)(3=66)(4=99)$ into polinteres

*left-right

recode q53 $(1=0)(2=11)(3=22)(4=33)(5=44)(6=55)(7=66)(8=77)(9=88)(10=99)$ into polor100.

*freedom and satisfaction with life

recode q9 q10 $(1=0)(2=11)(3=22)(4=33)(5=44)(6=55)(7=66)(8=77)(9=88)(10=99)$ into freedom satis.

* development of society

recode q54aa $(1=100)(\mathrm{else}=0)$ into revol.

recode q54aa $(2=100)($ else $=0)$ into reform.

recode q54aa $(3=100)($ else $=0)$ into evolu.

* interpersonal trust

recode $\mathrm{q} 8(1=100)(2=0)$ into trust.

* class

recode q110b $(1=0)(2=20)(3=40)(4=60)(5=80)(6=100)$ into class 6 .

* education

recode q94 $(1=0)(2=14)(3=28)(4=42)(5=56)(6=70)(7=84)(8=98)$ into edu. 